\title{
Materials Review
}

Sound Filmstrip Review: La Révolution française and L'Idée nationale au XIXe siècle, Educational Audio Visual Inc., Pleasantville, New York 10570; 2 filmstrips, 2 cassettes and teacher's notes for each program. \$38 per program.

La Révolution Française is treated in an orderly, rather traditional manner, beginning with the Ancien Régime but quickly proceeding to a discussion and illustration of events such as the meeting of the Etats Généraux, la Grande Peur, la Déclaration des droits de l'homme, the siege of the Bastille, the king's arrest at Varennes, le Manifeste de Brunswick, la Terreur Rouge, la Terreur Blanche, etc. As is the case in any general introduction to the Revolution, the student will be somewhat overwhelmed by the number of events, by the rapidity with which they took place, by the contradictions of the period. On the whole, however, the well-chosen quotations by Voltaire, Rousseau, and journalists, combined with the clear narration of events and the printed chronology in the notes, guide students through the period as well as is feasible in fifty minutes. Inevitably in such a complicated and rich epoch, each will wonder why certain items were left out or glossed over. From my point of view, for example, it seems regrettable that the Incroyables play no part, that the Cahiers de doléances are not emphasized, that the role of Louis the XVI's character is not dwelt upon, that more details of the Reign of Terror are not presented.

L'Idée nationale au XIXe siècle sketches the concept of nationalism from the Renaissance to Rousseau and then develops it in some detail during the Revolution, the Napoleonic era and the nineteenth century. The first half of the program tends to emphasize France (the Revolution and the Empire), the second all of Europe (the Germanic countries, France, Italy, the Balkans) and even Latin America up to 1914. Needless to say, discussion of a theme covering such a broad spectrum of time and space leads to a certain superficiality, and to but simple enumerations in a few instances. 
The two filmstrip programs have many fine qualities in common. Major ideas are presented forcefully and with great clarity in both. The French is very clear, well articulated and the quality of the recordings is uniformly excellent. In both, musical compositions from the periods are skillfully integrated on the cassettes as background. Extracts from philosophers, pamphleteers, politicians and men of letters are included and lend authenticity to the programs. The cassette text is available in printed form, so that the instructor or the student can check back on details he might have missed or misunderstood. There is an abundance of illustrations (over a hundred in each program): paintings, engravings, caricatures, objects of the period, portraits, maps (very good simple ones which avoid needless confusion). All this makes for, in each case, an interesting, lively, even entertaining albeit serious and generally nuanced presentation.

Unfortunately both programs share similar defects. If the engravings, caricatures, and maps are, on the whole, well, or at least adequately reproduced, the reproduction of paintings leaves something to be desired. The colors in works by Fragonard, Géricault and David, for example, are very poor, even unacceptable. This is especially true when one considers the fact that the paintings are major ones and that faithful prints are thus available. It would have been well had the authors identified the painters and dated the works, at least in the printed notes. Some teachers and most students will not be able to do this on their own without a good deal of research. It would likewise have been worth-while to indicate in the notes the composers and dates of the musical works played.

In spite of my reservations, I recommend these programs: Both can be put to good use in a French civilization course at the junior, senior, or graduate level. The Révolution could well be used as an introduction to or as a review of the period. It could also be used advantageously at the end of a course on eighteenth-century literature. The need for the program on nationalism is less immediately obvious. Most manuals and the majority of the professors of French civilization do not treat the nationalistic movement outside of France in the nineteenth century. Consequently, students are often totally ignorant of the period as far as the rest of Europe is concerned. This is unfortunate. If this program is presented to a class, the students will have at least a basic knowledge of the role of Metternich, Cavour, Garibaldi, Bismark, and of the Balkan question in the nineteenth century. Their study of the French Revolution, of Napoleon, of the Revolutions of 1830 and of 1848 will take on greater meaning when placed against this European backdrop. 